\title{
Hospitality of the People at the Tourism Destination and Destination Attractiveness of Akwa Ibom State, Nigeria
}

\author{
Ini Smart Udoh* \\ Department of Marketing, University of Uyo, Nigeria
}

*Corresponding Author: Ini Smart Udoh, Department of Marketing, University of Uyo, Nigeria

\begin{abstract}
This study set out to investigate the level of influences that Hospitality of the people at the tourism destination had on tourism destination attractiveness of Akwa Ibom State. Primary data were collected with the use of Questionnaire. A sample of 296 respondents, who were both domestic and foreign tourists visiting the state, made up our sample frame. The responses from the copies of questionnaire retrieved were analysed using a linear regression analysis. It was found that hospitality of the people at the tourism destination had a significant positive relationship on tourism destination attractiveness of Akwa Ibom State. It was concluded that tourists signified great importance on the hospitality of the people at the destination, and was a predictor of the tourism destinations' attractiveness of the state. It was recommended that the hospitable nature of the people at the destination could become a selling point of the destination, thus the tourism plan of the state should be designed to include basic orientations about the benefits of tourism to the State and their people.
\end{abstract}

Keywords: Hospitality, Tourism Destination, Destination Attractiveness, Destination Attributes.

\section{INTRODUCTION}

Tourism research has demonstrated that attraction studies are necessary in the understanding of the elements that encourage people to travel [1]. Every destination has its peculiar attributes and these attributes are supposed to be an important source of its attractiveness. Attractiveness of a destination is often expressed from the visitors' perspective based on their visit experiences.[2], defines a tourist as someone who spends at least an overnight stay at the destination, otherwise is classified as an excursionist.

There is a broad assertion among authors that the overall attractiveness of a destination depends on the actual experience of the visitors with the tourism attributes [3]. Literature evidence have also shown that there is a plethora of interdependencies between a tourism destination and the receptiveness of its host to visitors [4]; [5]. The social interaction between tourists and local people is crucial in attracting people to a destination [4].

It is interesting to know that despite empirical research and theoretical studies dedicated to tourism destination attractiveness factors and their perceived importance, it appears that there continues to be shortage of studies especially in Nigeria devoted to specifically understand the hospitable role played by the host people at the destination in creating an impression in the minds of tourists about the destination's attractiveness. Also, there has been large focus on other context of destination attractiveness especially on environmental, historical cultural festivity features of the destinations, giving less consideration to the role of the host people.

The objective of this study is to assess the relationship between hospitality of the people at the tourism destination and destination attractiveness of Akwa Ibom State. The main question to be answered here is what relationship exists between hospitality of the people at the tourism destination and the destination attractiveness of Akwa Ibom State? Considering similar studies have been carried out in other developed nations and have indicated that a relationship thus exists. This paper thus seeks to contribute to the already existing literature on the role of the host people at tourism destinations in strengthening the image or attractiveness of the tourism destination, using Akwa Ibom State, Nigeria as the study area.

The hypothesis of the paper thus states that; 
$\mathbf{H}_{\mathbf{0}}$ : Hospitality of the people at the tourism destination does not have any significant positive influence on the destination attractiveness of Akwa Ibom and Cross River States

The paper is divided into sections. There is a review of academic literature on hospitality of the people at tourism destinations, as well as an overview of the concept of destination attractiveness. This is followed by the research method, results of data analysis and interpretation of findings. The discussion section will better describe our findings and give implications of the study's findings.

\section{LITERATURE REVIEW}

\subsection{Hospitality of the People at the Tourism Destination}

Personal relationship sometimes has a reciprocal Nature [6]. Some studies assume that locals are attracted to tourists because they assume that the keenness to develop personal relationships is a sign of friendliness [7]. According to [8] when tourists visit a destination, they seek more than one experience at the destination. They stay in accommodations, go out to eat and drink, seek entertainments and in the process, communicate and interact with the local people. Hospitality is thus an expression of friendliness, receptiveness and welcome by residents to tourists arriving in their community ([9]). Friendliness and hospitality of the locals is one of the principal destination attributes that leads to tourist satisfaction [10]; [8]; [11]. It is assumed that tourists would hardly consider visiting places with high risk factors. On the other hand, visitor's interest in the community is a source of local pride. Seeing visitors' interest in the community makes residents more appreciative of local resources that are often taken for granted [12].

Hospitality of the people at a tourism destination could be expressed through kindness, and traditional hospitality [13]. Local people's attitude towards tourists is a major social factor forming part of the macro-environment of a destination [14]. Their attitude towards tourist is determined by how they perceive the tourism industry. Residents of a certain destination may perceive tourism in a positive or a negative way. This may lead to a friendly or unfriendly attitude towards tourists [15]. [16] argue that residents' support for tourism development can foster a competitive destination. Hence local people's attitude towards tourists is very important for the long-term success of tourism in a destination. [15] Adds that if tourists are greeted with hostility in the destination, they are not likely to visit the destination again.

Not much literature emphasizes the importance of the hospitality of the people resident in the destination on tourism. Existing literatures have mainly looked at the effect of tourism on the host community rather. One cannot ignore the part played by the indigenous people in hosting tourist when they visit. Tourists are likely to create a perception about a destination, through the attitudes shown to them by the residents of the destination. This influences their decision to revisit or recommend the destination to others in a positive or negative light.

\subsection{Overview of Tourism Destination Attractiveness}

The concept of tourism destination attractiveness has received much attention in tourism literature [17]; [18]; [1]; [19]; [20]; [21]; [22]; [23]; [24]; [25]; [26]; [27]; [28]; [29]; [30]. The word attractiveness itself originates from the Latin verb "atrathere", meaning-to attract [31].

The attractiveness of a destination depends on the relationship between the availability of existing attractions and the perceived importance of such attractions [1] and their ability to deliver benefits to tourists (demand) [5]. According to [23]; [32]; [33], the influence of destination attractiveness on tourist intention to visit a destination is not limited to the stage where tourist select where to visit, but also affects the behavior of tourists in general. It is noted that destination attractiveness is the most significant predictor of revisit intention.

A tourist destination is a geographical location which has the necessary components to attract tourists and meet their needs, [34]. [31] States that tourism attractions form an essential part of tourism destinations and that they are one of the four key segments of the tourism system. According [35] the four key segments that make up a tourist destination which he referred to as the 4A's are: Attractions which consist of the artificial as well as natural features or events; Amenities which include accommodation, food, entertainment and recreation; Access in terms of development and maintenance of transport which provides the link to the tourist destination and the tourist attractions at the destination; and Ancillary services which are provided to customers and industry by the destination through a local tourist board. 


\subsection{Theoretical Framework}

This study draws its theoretical evidence from the Leiper's tourism attraction system model. The model was created by Neil Leiper in 1979 and later updated in 1989 and 1990.Leiper's model presents a framework which enables the definition of tourism as a system. According [36], Leiper's (1990) model defined tourism as a system composed of three (3) key dimensions: the tourist-who is the main element of the system; the space- which is divided into three geographical regions (a traveler generating region, a destination region and the travel and tourism industry); and the travel and tourism industry- which include the system of entrepreneurial and organizational activities that are involved in the production of tourism services. The tourism system approach as proposed by [37] has been applied in several studies by many authors, [38]; [39]; [40]; [36]. Some scholars claim that without the elements that make up attractiveness, tourism is impossible [31] Others believe that it is the demand for an element in the location that makes up the attractiveness of the destination and propels tourists to visit [36]; [41] This study thus bases its support on the tourism system approach to provide an understanding of how hospitality of the people at the tourism destination could enhance the attractive image of the destination. It therefore regards Hospitality of the people at the tourism destination as a unit of the destination region that could influence tourist perception of the destination's attractiveness.

\section{RESEARCH METHOD}

The study area was Akwa Ibom State in Nigeria, located in the coastal South-south part of the country. The state lies between latitudes $4^{0} 32$ and $5^{0} 33$ North and longitudes $7^{0} 25$ and $8^{0} 25$ East. Akwa Ibom was created out of the old Cross River State, with Uyo being it's the administrative capital. The main languages spoken here are Ibibio, Annang and Oron languages. Akwa Ibom state is divided into 3 Local Government Areas. The state is currently one of the highest visited tourism destinations in the country and the people of the state are known for their warmth and hospitality which are expressed in various languages, dances, festivals, association with visitors, handcrafts and cuisines.

The survey research design was adopted to gather information from respondents. The population of this study consists of all domestic and international tourists who were visiting Akwa Ibom State. It covers those that were found at various tourist attractions in the State. This constituted an unknown population. To determine the sample size for this study, the Top man formula was adopted. The adoption of this Formula is to enable us get a sample size for the study which has an unknown population record of tourist that visit the state annually. Thus, to arrive at an appropriate sample size for the study, a pilot study was carried out, using the research questionnaire on 30 selected on sight visitors/guests that were encountered by the researcher at tourism attractions in the state. Based on the formula, 296 respondents formed the sample size for the study. The sampling technique adopted for this study was the Convenience Sampling, which is a non-probability sampling technique. The method allows the researcher conveniently collect data from many respondents, the emphasis here is on accessibility to the target respondents. The instrument for primary data collection for this study was a structured, measured on a ' 5 ' point Likert scale. Where ' 4 ' was the highest positive attitude response to the question, "through ' 0 ' being the lowest attitude response to the questions. The questionnaire consisted of multiple closed ended questions, measuring the dependent and independent variables. The research instrument had both face and content validity. The Cronbach's Alpha was used to measure consistency at 0.62 which shows that the instrument was reliable. Data were presented and analyzed using such statistically descriptive tools as tables, percentages, and frequencies. The regression analysis was adopted for this study to predict the relationship that exists between hospitality of the people at the tourism destination and destination attractiveness of Akwa Ibom State.

\section{RESUlT AND DISCUSSION}

\subsection{Data analysis and Presentation}

To determine the significant relationship as well as strength of relationship that exist between the independent variable $(\mathrm{X})$ and tourism destination attractiveness $(\mathrm{Y})$ the dependent variable, the Linear regression analysis was used. This enabled us predict the expected changes in the dependent variable $(\mathrm{Y})$, given a unit change in the independent variable( $\mathrm{X})$, in the regression equation. Given ' $\mathrm{Y}$ ' as a function of ' $\mathrm{X}$ '; 
Hospitality of the People at the Tourism Destination and Destination Attractiveness of Akwa Ibom State, Nigeria

$\mathrm{Y}=\mathrm{f}(\mathrm{X})$

$\mathrm{Y}=\mathrm{a}_{0}+\mathrm{b} \mathrm{X}+\mathrm{e}$

All hypotheses were tested at 0.05 level of significance.

From a total of 296 copies of questionnaire administered within 3 months (November 207 - January 2018), only280 representing $94.6 \%$ were found useable on retrieval. The researcher considered the $94.6 \%$ as an adequate representation of the sample size chosen for this study and therefore proceeded with the analysis. Results of linear regression showed;

Table4.7. Model Summary ${ }^{d}$

\begin{tabular}{|c|l|l|l|l|}
\hline Model & \multicolumn{1}{|c|}{$\mathbf{R}$} & R Square & Adjusted R Square & Std. Error of the Estimate \\
\hline & $.517^{\mathrm{a}}$ & .267 & .262 & 2.02516 \\
\hline
\end{tabular}

a. Predictors: (Constant) Hospitality

b. Dependent Variable: Attractiveness

Table4.8. $A N O V A^{a}$

\begin{tabular}{|l|l|l|l|l|l|l|}
\hline \multicolumn{2}{|c|}{ Model } & Sum of Squares & df & Mean Square & F & \multicolumn{1}{c|}{ Sig. } \\
\hline \multirow{5}{*}{} & Regression & 44.057 & & 207.029 & 50.479 & $.000^{c}$ \\
\cline { 2 - 7 } & Residual & 1136.053 & 277 & 4.101 & & \\
\cline { 2 - 6 } & Total & 1550.111 & 279 & & & \\
\hline \multicolumn{2}{|l|}{ Total } & 550. & 279 & & & \\
\hline
\end{tabular}

a. Dependent Variable: Attractiveness

b. Predictors: (Constant), Hospitality

Table4.9. Coefficients

\begin{tabular}{|l|l|l|l|l|l|}
\hline \multirow{2}{*}{ Model } & \multicolumn{2}{|c|}{ Unstandardized Coefficients } & Standardized Coefficients & \multirow{2}{*}{ t } & \multirow{2}{*}{ Sig. } \\
\cline { 2 - 5 } & \multicolumn{1}{|c|}{ B } & Std. Error & & & \\
\hline (Constant) & 5.235 & 1.077 & .196 & 4.862 & .000 \\
\hline Hospitality & .262 & .075 & 3.488 & .001 \\
\hline
\end{tabular}

a. Dependent variable: Attractiveness

\section{DisCUSSION OF FINDINGS}

We found that regression sum of squares 44.057 out of 1550.111 , represents the model's ability to explain $\mathrm{R}^{2}=26.7 \%(0.267)$ of the variations in tourism destination attractiveness (the predictor variable). Thus, $73.3 \%$ of the change in Tourism Destination Attraction was unexplained by the model, indicating that destination attractiveness was a function of a wider range of attributes present at that destination.

Test of Hypothesis $\left(\mathrm{H}_{0}\right)$; The hypothesis states that hospitality of the people at the tourism destination does not have any significant positive influence on the destination attractiveness of Akwa Ibom and Cross River States.

From the analysis, hospitality of the people at the tourism destination had a significant positive relationship with tourism destination attractiveness, since $t=3.488$ and the $p$-value $=0.001$ is less than 0.05 ( $\mathrm{p}$-value $=0.00<0.05)$. The null hypothesis was therefore rejected and the alternative hypothesis was accepted. This is an indication that hospitality of the people at the tourism destination had an impact on the destination's attractiveness with a regression co-efficient of $b_{2}=0.262$. The

Regression co-efficient shows that for every unit increase in hospitality of the people at the tourism destination, a $26.2 \%$ unit increase in destination attractiveness is predicted.

The resulting model will be;

$\mathrm{Y}=\mathrm{a}_{0}+\mathrm{bX}+\mathrm{e}$

Tourism Destination Attractiveness $=5.235+0.262 \mathrm{X}+\ldots \mathrm{e}$

Hospitality is regarded as a function of how friendly, kind and receptive the hosts are to visitors. Accordingly, we infer that hospitality of people at the destination is an important characteristic of the 
tourism destination and had a strong influence on tourist's impression and decision to visit the destination. By implication, this is an indication that tourists are not attracted to visit destinations that are characterized by hostility and unfriendliness of the populace. Thus, the decision to re-visit in the future, project or even recommend the destination to others are often influenced by the impression held about the hospitable nature of the people. The result obtained in this study is in consonance with Thiumsak and Ruangkanjanases (2016) that friendliness of the locals could become a major selling point for marketers in the tourism industry, who could substantially communicate the positive image of the destination to tourists and intending tourists, by emphasizing on the friendliness of the people.

\section{RECOMMENDATION}

It has been realised that Akwa Ibom state is fast growing in its popularity as a choice tourism destination. Thus, a guest history data base should be created to gather the statistics of visitors that come into the states for different tourism related purposes. This information would enable the government and other tourism stakeholders to see a need to create and add innovations to their offerings so as to meet the fast-growing tourism status of the state.

The tourism plan of the state should be designed to include basic orientations about the benefits of tourism to the State and their people. Emphasis should be made on educating the locals on how their hospitality and attitude towards tourists could have a positive impact on their reputation as a state. This is because impression gathered during tourist's contacts with the locals is paramount in the business of tourism.

\section{CONCLUSION}

The findings of the study had attempted to answer the research question on what relationship exists between hospitality of people at the destination and destination attractiveness. It was revealed in the study that tourists placed priority on the hospitality of the people at the destination, expressed in the way they interact, their receptiveness to visitors and the peaceful nature of the place and its people. The coefficient of regression from the analysis showed that hospitality variable is a predictor of destination attractiveness.

\section{SUGGESTION FOR FURTHER STUDIES}

Based on the result of finding, it is suggested that other variables be used in measuring the tourism destination attractiveness along with the hospitality of the hosts, to ascertain the weight of influence other variables may have on destination attractiveness. This would allow for a clearer picture on those variables that tourist focus their tourism experience on.

\section{REFERENCES}

[1] Formica, S. and Uysal, M. (2006). Destination attractiveness based on supply and demand evaluations: An analytical framework. Journal of Travel Research, Vol. 44, pp. $418-430$

[2] WTO (2014). Glossary of tourism terms. Available at http://cf.cdn.unwto.org/sites/all/files/Glossary+ of+terms.pdf. Retrieved on 19 March 2017.

[3] Das, D., Sharma, K.S., Mohapatra, P.K.J., and Sarkar, A. (2007). Factors influencing theattractiveness of a Tourist Destination. Journal of Services Research, 7(1), 103-134.

[4] Smith, V. (2000). Hosts and guests: The anthropology of tourism. Philadelphia: Philadelphia University Press.

[5] Vengesayi, S., Mavondo, F. T., \& Reisinger, Y. (2009). Tourism destination attractiveness: attractions, facilities, and people as predictors. Tourism Analysis, 14, 621-636.

[6] Page, S.J., and Connel, J. (2007). Tourism: A modern Synthesis. London; Thomson Learning.

[7] Cohen, E. (2000). The Commercialized Crafts of Thailand: Hill Tribes and Lowland Villages: Collected Articles. Hawaii: University of Hawaii Press.

[8] Kozak, M., \&Rimmington, M. (1998). Benchmarking: Destination attractiveness and small hospitality business performance. International Journal of Contemporary Hospitality Management, 10, 184-188.

[9] Suanmali, S. (2014). Factors Affecting Tourist Satisfaction: An Empirical Study in the Northern Part of Thailand. 4th International Conference on Tourism Research (4ICTR), 12(9), 1-9.

[10] Jenkins, O.H. (1999). Understanding and measuring tourist destination images. International Journal of Tourism Research, 1(1), 1-15.

[11] Yoon, Y. and Uysal, M. (2005). An Examination of the Effects of Motivation and Satisfaction on Destination Loyalty: A Structural Model. Tourism Management, 26(1), 45-56. 
Hospitality of the People at the Tourism Destination and Destination Attractiveness of Akwa Ibom State, Nigeria

[12] Glenn, K. (2001). The impacts of tourism. Retrieved from http://www.seagrant.umn.edu/tourism/pdfs/ ImpactsTourism.pdf on March 15, 2017.

[13] Perović, D.; Stanovčić, T.; Moric, I. \&Pekovic, S. (2012). What socio-demographic characteristics do influence the level of tourist's satisfaction in Montenegro? Empirical analysis. Journal of Tourism, 14, 5-10.

[14] Dwyer, L. and Kim, C. (2003). Destination Competitiveness: Determinants and Indicators. Current Issues in Marketing Journals, 6(5), 369-414.

[15] Zhou, L., (2005). Destination Attributes that attract International Tourists to Cape town (Master's thesis). University of the Western Cape, Faculty of Economic and Management Sciences, Cape Town, South Africa.

[16] Kim, H, and Richardson, S.L, (2003). Motion picture impacts on destination images. Annals of Tourism Research, Vol 30, No. 1, pp 216-237.

[17] Ferrario, F. (1979). The Evaluation of Tourist Resources: An Applied Methodology. Journal of Travel Research, 17 (3), 18-22 and 17(4), 24-30.

[18] Formica, S. (2001). Destination attractiveness as a function of supply and demand interaction (Doctoral Thesis). Virginia Polytechnic Institute and State University, Department of Hospitality and Tourism Management, Virginia, U.S.A.

[19] Gearing, C.E., Swart, W., and Var, T. (1974). Establishing a measure of Touristic attractiveness. Journal of Travel Research, 12, 1-8.

[20] Hu, Y. \& Ritchie, J.R. B. (1993). Measuring destination attractiveness: A contextual approach. Journal of Travel Research, 32(2), 25-34.

[21] Kim, H. B. (1998). Perceived attractiveness of Korean destinations. Annals of Tourism Research, 25, 340 361.

[22] Kim, S. S., \& Lee, C. K. (2002). Push and pull relationships. Annals of Tourism Research, 29(1), $257-260$.

[23] Kozak M., and Rimmington, M. (1998). Benchmarking: Destination attractiveness and small hospitality business performance. International Journal of Contemporary Hospitality Management, 10 (5), 184-188.

[24] Krešić D., \& Darko Prebežac, D. (2011). Index of destination attractiveness as a tool for destination attractiveness assessment. Original Scientific Paper, 59(4), 497-517.

[25] Nyberg, L. (1994). Determinants of the attractiveness of a tourism region. In S. F. Witt \& L. Moutihno (eds), Tourism marketing and management handbook (2nd ed., 24-28). New York: Prentice Hall.

[26] Tam, B. T. (2012). Application of contextual approach for measuring tourism destination attractiveness. Journal of Science, 70(1), 217-226.

[27] Tasci, A. D. A., Cavusgil S. T., \& Gartner, W. C. (2007). Conceptualization and operationalization of Destination Image. Journal of Hospitality \& Tourism Research. 31, 194.

[28] Vengesayi, S. (2003). A conceptual model of tourism destination competitiveness and attractiveness, ANZMAC Conference Proceedings, 637-647, Adelaide, University of South Australia, 1-3 December.

[29] Vengesayi, S., Mavondo, F.T. and Reisinger, Y. (2009). Tourism Destination attractiveness: Attractions, facilities, and people as predictors. Tourism Analysis, Vol. 14, pp. 621-636.

[30] Ariya, G, Wishitemi, B. and Sitati, N. (2017). Tourism Destination Attractiveness as Perceived by Tourists Visiting Lake Nakuru National Park, Kenya. International Journal of Research in Tourism and Hospitality, 3(4), 1-13.

[31] Gunn, C.A. (1988). Vacationscape: Designing Tourist Regions (2nd ed). New York: Van Nostrand Reinhold.

[32] Sparks, B. (2007). Planning a wine tourism vacation? Factors that help to predict tourist behavioral intentions. Tourism Management, 28, 80-92.

[33] Um, S., Chon, K., \& Ro, Y.H. (2006). Antecedents of revisit intention. Annals of Tourism Research, 33, 4-58.

[34] Pearce, D. (1992). Tourist Development. New York: Longman.

[35] Cooper, C.P. Fletcher, J., Gilbert, D. and Wanhill, S. (2000). Tourism Principles and practice, (2nd Ed.), London; Pitman Publishing.

[36] Candela, G. and Figini, P. (2012). The Economics of Tourism Destinations. Berlin; Springer Heidelberg.

[37] Leiper, N. (1990). Tourist attraction systems. Annals of Tourism Research, 17(3), 379-381.

[38] Cooper, C.P. and Boniface, B.G. (1994). Geography of Travel and Tourism. Butterworth-Heinemann; Oxford.

[39] Henshall, B.D. and Roberts, R. (1985). Comparative assessment of tourist generating markets for New Zealand. Annals of Tourism Research, 12(2), 219-238. 
Hospitality of the People at the Tourism Destination and Destination Attractiveness of Akwa Ibom State, Nigeria

[40] Hing, N. and Dimmock, K. (2000). From Bula to bust: Events, reactions and recovery strategies for tourism surrounding Fiji's 2000 coup d'état. International Journal of Contemporary Hospitality Management, 1(1), 136-148.

[41] Dale, F. (1990). Consumer perceptions of Tourist attractions. Journal of Travel Research, 28 (4), 3-10.

[42] Tourism Destination and Tourist Attraction Destination Marketing Tourism Essay (2016). Accessed from https://www.ukessays.com/essays/tourism/tourism-destination-and-tourist-attraction-destinationmarketing-tourism-essay.php. Retrieved on 9 October 208.

Citation: Ini Smart Udoh. "Hospitality of the People at the Tourism Destination and Destination Attractiveness of Akwa Ibom State, Nigeria". International Journal of Research in Tourism and Hospitality (IJRTH), vol 5, no. 2, 2019, pp. 1-7. doi: http://dx.doi.org/10.20431/2455-0043.0502001.

Copyright: (C) 2019 Authors. This is an open-access article distributed under the terms of the Creative Commons Attribution License, which permits unrestricted use, distribution, and reproduction in any medium, provided the original author and source are credited. 